American Journal of Agricultural and Biological Sciences 6 (3): 307-316, 2011

ISSN 1557-4989

(C) 2011 Science Publications

\title{
Suppression of Salicylic Acid-Mediated Plant Defense Responses During Initial Infection of Dyer's Woad by Puccinia thlaspeos
}

\author{
${ }^{1}$ Elizabeth Thomas and ${ }^{2}$ Bradley R. Kropp \\ ${ }^{1}$ Department of Plant Pathology, NC State University, Raleigh, NC 27695, USA \\ ${ }^{2}$ Department of Biology, Utah State University, Logan, Utah 84322, USA
}

\begin{abstract}
Problem statement: Puccinia thlaspeos is a microcyclic rust pathogen that is being investigated as a potential biocontrol agent of the noxious weed, dyer's woad (Isatis tinctoria). Although, the initial events in the colonization of dyer's woad by the rust pathogen has been elucidated using scanning electron microscopy and PCR, little is known regarding the susceptibility response of this plant to its rust pathogen. Approach: The induction kinetics and amplitude of the Salicylic Acid (SA)-responsive Pathogenesis-Related (PR) genes, PR-1, $\beta$-1, 3-glucanase and ChiA in the compatible interaction between the rust pathogen Puccinia thlaspeos and dyer's woad were examined during the first $72 \mathrm{~h}$ of the infection process. Furthermore SA, an inducer of plant defense response was applied to infected plants in order to reprogram the host defense response at periods that coincided with key events of the infection process. Results: PR genes were upregulated following host penetration by the pathogen. A subsequent pathogen-mediated suppression of PR genes was seen that corresponded with haustorium formation. This was followed by a second up-regulation of these genes that was, in turn, followed by a second long-term pathogen-induced suppression of the defense response that appears to allow successful infections in dyer's woad. Exogenous application of SA to uninoculated plants led to activation of defense responses by $8 \mathrm{~h}$ after treatment. In treatments where inoculated plants were treated with SA, responses differed depending on the timing of SA application. Application of SA at times corresponding to the pre-haustorial and posthaustorial phases of infection triggered an up-regulation of defense genes and increased protection against the pathogen. However, the application of SA during haustorium formation could not override the pathogen-mediated suppression of defense responses and consequently, did not offer the host increased protection. Conclusion: Although pathogen-induced PR expression was observed during rust infection of dyer's woad, it appears to be insufficient to inhibit fungal growth during the compatible interaction between dyer's woad and the rust pathogen. Suppression of pathogeninduced host defense responses during and after haustorium formation is postulated to be vital in the establishment of biotrophy in this system.
\end{abstract}

Key words: Gene expression analysis, plant defense response, rust fungi, salicylic acid, compatible interaction, biotrophy, biocontrol, obligate biotroph, induction kinetics, dyer's woad, Isatis tinctoria, Puccinia thlaspeos

\section{INTRODUCTION}

Puccinia thlaspeos an autoecious microcyclic rust pathogen, is a potential biocontrol agent of the brassicaceous noxious weed, dyer's woad (Isatis tinctoria L.) (Kropp and Darrow, 2006; Kropp et al., 1996; 2002). When the rust pathogen attacks dyer's woad, the plant becomes thoroughly colonized during the first growing season and remains asymptomatic until the second year of its life cycle. When the plants bolt during the second growing season, the leaves become chlorotic and malformed. As the season progresses, spermatia develop on the leaves, followed by dark brown telia as the tissue matures. Bolted plants have twisted flower stalks and produce few seeds, making the rust pathogen an effective biocontrol agent for dyer's woad.

Like all other rusts, P. thlaspeos is an obligate biotroph that benefits by keeping its host alive until the completion of its life cycle. By nature, most obligate biotrophs cause little damage to the host plant, produce limited amounts of lytic enzymes and have a narrow host range (Cooper, 1984; Mendgen and Hahn, 2002; Panstruga, 2003). However, the invasion of plant tissue 
by a pathogen does lead to the rapid induction of complex defense responses by the plant. An important response to this invasion is the synthesis of Pathogenesis-Related (PR) defense proteins. Signaling molecules such as Salicylic Acid (SA), ethylene, jasmonic acid, nitric oxide and hydrogen peroxide can induce PR proteins. However in response to obligate biotrophs, plants appear to primarily use SA as a signaling molecule (Glazebrook, 2005; Thomma et al., 2001). PR proteins have been found to have antifungal properties in vitro through hydrolytic activity of cell walls (Mauch et al., 1988; Sela-Buurlage et al., 1993). Currently, there are 17 families of PR proteins that occur widely in plants and represent a major aspect of plant defense responses to pathogenic attack (Van Loon et al., 2006).

A significant amount of research has been devoted to understanding the resistance gene mediated response to plant pathogens (Dodds et al., 2004; 2006; Flor, 1956; 1971; Glazebrook, 2005) while nonhost resistance has been studied to a lesser extent (Heath, 2003; Mellersh and Heath, 2003; Thordal-Christensen, 2003). However, the susceptibility response to obligate biotrophs such as the rusts has not been well defined (Panstruga, 2003). This is primarily because of the difficulties associated with the in vitro culturing of an obligate biotroph, as well as, the inability to attain uniform germination of the teliospore that is vital in dissecting rust-host interactions. Although, the sequence of events beginning from basidiospore germination, entry into the host plants and the eventual colonization of dyer's woad by the rust pathogen has been clearly elucidated using scanning electron microscopy and PCR, little is known regarding the susceptibility response of this plant to its rust pathogen (Kropp et al., 1999). The aim of this study was to examine expression of SA-mediated defense genes by dyer's woad during infection and colonization by the rust pathogen $P$. thlaspeos. It tested the hypothesis that suppression of pathogen-induced host defense responses corresponds with critical events in the infection process and had the following goals: (i) to understand the dynamics of teliospore and basidiospore germination in order to facilitate dyer's woad rust infections, (ii) to isolate homologs of PR-1, $\beta-1,3-$ glucanase and ChiA in dyer's woad, (iii) to determine the induction kinetics of PR-1, $\beta$-1, 3-glucanase and ChiA during rust penetration, haustoria formation, and colonization of dyer's woad and (iv) to examine disease resistance in dyer's woad following the exogenous application of salicylic acid.

\section{MATERIALS AND METHODS}

Inoculum calibration: To accurately determine the kinetics of host defense response, the application of standard amounts of inoculum was necessary in all treatments. To calibrate delivery of basidiospore inoculum, leaf pieces carrying teliosori were surfacedisinfested for $2 \mathrm{~min}$ in $0.6 \%$ sodium hypochlorite and rinsed thoroughly with sterile distilled water. They were placed on water agar plates with teliosori facing outward. The plate was inverted so that the teliosori were positioned directly over corresponding water agar disks held on a microscope slide. The plates were incubated in the dark, in a dew chamber at $15^{\circ} \mathrm{C}$ with parameters set for dew formation (Gold and Mendgen, 1983; Kropp et al., 1996). The plates with teliosori were either inverted over the disks immediately after preparation, or $6 \mathrm{~h}$ after preparation to account for a lag in germination. They were incubated for 8, 12, 24 and $48 \mathrm{~h}$ and after each time period, the water agar disks were fixed and stained using $1 \%$ lactofuchsin to facilitate counting of the spores. The total number of basidiospores that were released from the teliospores and the number that had germinated were determined by viewing and averaging counts from 10 fields on each water agar disk using a microscope at $400 \times$. The number of basidiospores was expressed as mean of three replicate experiments.

Rust inoculation and SA treatment of dyer's woad: Dyer's woad plants were grown following the method of Kropp et al. (1996). Plant inoculations were done with inoculum prepared from leaves of diseased dyer's woad plants (Thomas and Kropp, 2011). Leaf pieces containing the inoculum were surface-disinfested in $0.6 \%$ sodium hypochlorite and positioned on a water agar plate with the teliosori facing upward so that they could be inverted over the leaf surface. The teliosori were consistently arranged on the plate so that only the apical two $\mathrm{cm}$ of the leaves would be saturated with basidiospores. For each experimental treatment, the number of teliosori used were adjusted based on predetermined germination rates to deliver 100 basidiospores with a $50 \%$ germination rate per square mm of host leaf surface (Thomas and Kropp, 2009; 2011). All inoculations were conducted after incubating the inoculum for $6 \mathrm{~h}$ on the agar plates and were carried out at night in a dew chamber at $15^{\circ} \mathrm{C} \pm 1$. An equal number of mock-inoculated control plants were prepared simultaneously with the inoculated plants. All inoculated plants were held for $8 \mathrm{~h}$ in the dew chamber at which time sampling had begun. The plants were transferred to a greenhouse for the duration of the 
study. Both inoculated and control plants were sampled $8,12,16,24,36,48$ and $72 \mathrm{~h}$ after inoculation. An additional positive control for the systemic activation of pathogenesis-related genes in infected plants was created by spraying seedlings with $75 \mathrm{~mL}$ of $1 \mathrm{mM}$ of salicylic acid (Sigma, St. Louis, MO) using a handheld sprayer. These plants were incubated under greenhouse conditions until assayed 8, 12, 16, 24, 36, 48 and $72 \mathrm{~h}$ after treatment. All of the above treatments consisted of three biological replicates at each time point.

Because early infections of dyer's woad by $P$. thlaspeos are asymptomatic, infection of inoculated leaves was confirmed by detecting fungal DNA in the leaves using universal and rust-specific ITS PCR primers (Kropp et al., 1996). The universal primers used as a check to ensure the presence of amplifiable DNA in the leaf samples included F63 (5'GCATATCAATAAGCGGAGGAAAAG- 3') and R635 (5'-GGGTCCGTGTTTCAAGACGG-3') while the second rust-specific primer set, F63 and Rust1 (5GCTTACTGCCTTCCTCAATC-3') was used to detect the presence of rust infections in the leaf samples.

Primer design, quantitative real-time PCR and relative quantitation of gene expression: Primers designed from the sequences of defense-related transcripts of PR-1, B-1, 3-glucanase and ChiA from Brassica napus and Arabidopsis thaliana in Genbank were used to identify sequences in dyer's woad. After verification of sequences from dyer's woad, new woadspecific primers were designed using Primo Pro 3.4 (Table 1). Primers were also designed for the internal control gene, Actin.

To study induction kinetics of defense-related genes in response to various treatments, total RNA was extracted from plants at each time point using RNeasy Plant Mini kit (Qiagen, Valencia, CA). After an oncolumn DNase digestion with Qiagen's RNase-free DNase, RNA quality was analyzed using the Bio Analyzer (Agilent 2100 Bioanalyzer, Agilent Technologies, Waldbronn, Germany) and quantified spectrophotometrically using a NanoDrop ND100 (NanoDrop Technologies, Wilmington, DE). Synthesis of cDNA was done using the First Strand cDNA synthesis kit (Fermentas Inc., Glen Burnie, MD).

Quantitative real time PCR was carried out using the Smart Cycler System (Cepheid, Sunnyvale, CA). Real-time PCR was conducted using iTaq SYBR Green Supermix with ROX (Bio-Rad Laboratories, Hercules, CA). The target cDNA in each biological replicate for all treatments was assayed four times, amounting to four technical replications. Amplification parameters were one cycle at $95^{\circ} \mathrm{C}$ for $3 \mathrm{~min}$, followed by 50 cycles at $95^{\circ} \mathrm{C}$ for $15 \mathrm{sec}, 60^{\circ} \mathrm{C}$ for $30 \mathrm{sec}$ and $72^{\circ} \mathrm{C}$ for $30 \mathrm{sec}$. Melt curve analysis was performed after amplification for each target gene and transformed to the negative first derivatives for use in identifying the specific PCR product.

The induction kinetics of defense-related genes was studied by the relative quantitation of gene expression, using the standard curve method (ABI Prism 7700 Sequence Detection System, User Bulletin 2. PE Applied Biosystems, Foster City, CA). Standard curves were constructed for each of the target genes and the endogenous control, Actin. For each biological sample, the amounts of the target and the Actin gene were estimated from the relevant standard curve. The values obtained were normalized by dividing the amount of the target by the amount of the Actin gene expression. The normalized amount in the rust and SA treatments was divided by the normalized amount in the healthy and untreated controls to compute relative changes in gene expression. Means and the standard errors were estimated from these values.

Effect of SA on rust infection: The effect of inducing defense responses during key events in pathogen establishment was examined by applying SA to dyer's woad plants at different times either before or after rust inoculation. To study the effect of SA-induced defense response prior to rust inoculations, SA was applied $12 \mathrm{~h}$ prior to inoculation so that peak defense gene expression occurred before inoculation. SA was also applied $8 \mathrm{~h}$ prior to inoculation so that peak defense gene expression coincided with penetration of plant tissues by the rust fungus (Kropp et al., 1999). Finally, SA was applied at the time of inoculation so that peak defense gene expression coincided with the prehaustorial phase of rust infection (Kropp et al., 1999). To study the effect of SA-induced plant defense responses on infection rates after rust inoculation, SA was applied to the plants $4 \mathrm{~h}$ after rust inoculation when the pathogen would have produced intercellular hyphae (Kropp et al., 1999) and again 8, 12 and $24 \mathrm{~h}$ after rust inoculations.

For all experiments, SA was applied by spraying $75 \mathrm{~mL}$ of a $1 \mathrm{mM}$ preparation onto 4-week-old plants. Control plants were sprayed with water in lieu of SA and inoculated with the rust pathogen. Each treatment consisted of 10 replicate plants arranged in a completely randomized design. The plants were incubated for three weeks, after which DNA was extracted from the leaves away from the point of inoculation using the Extract-N-Amp Plant PCR kit (Sigma, St. Louis, MO) and infection rates estimated. 
Am. J. Agri. \& Biol. Sci., 6 (3): 307-316, 2011

Table 1: Woad- specific primer pair sequences used in the study

\begin{tabular}{llll}
\hline Gene & Primer pairs & Primer & Genbank accession No. \\
\hline PR-1 & ItPR1AF & CTGCAGACTCGTACACTCC & EU684740 \\
& ItPR1AR & TACACCTCACTTTAGCACATC & EU684742 \\
Chis & ItBGLF & CTCTGCTCTTGAATAACTACCC & \\
& ItBGLR & CCAACCGCTCTCTGACACC & EU684739 \\
Actin & ItCHAF & TAGGTGATGCTGTTCTTGATG & AY870652 \\
& ItCHAR & TGGAAATGGACACTGAGGAG & \\
\hline
\end{tabular}

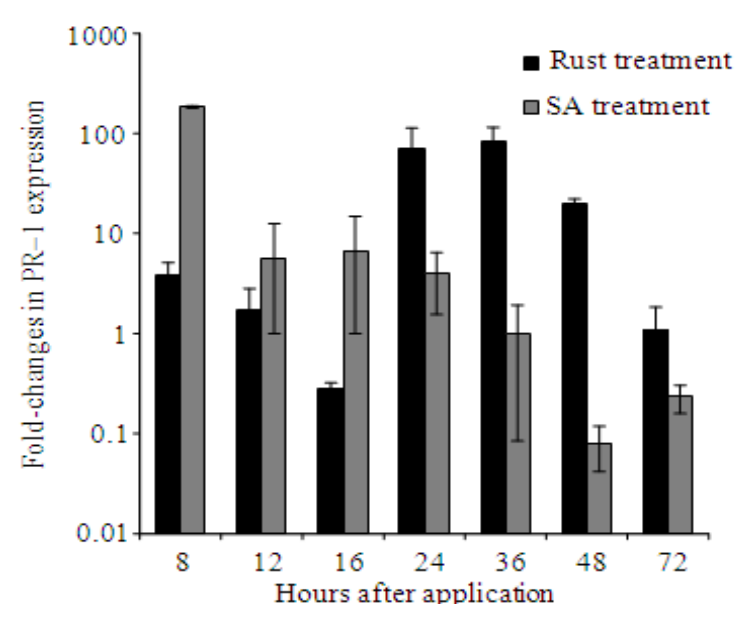

Fig. 1: Relative gene expression of PR-1 seen as a result of treating dyer's woad either with the rust pathogen or $1 \mathrm{mM}$ salicylic acid. Transcript levels were determined using qPCR. Values were normalized with the Actin gene. Each data point was generated from 12 amplifications (3 biological replicates $\mathrm{x} 4$ technical replicates) and is reported as mean $( \pm$ S.E. $)$

Statistical analysis: Changes in gene expression were computed using Microsoft Excel 2003 software (Microsoft Corporation, Redmond, WA). Fold changes in gene expression were reported as mean $\pm \mathrm{SE}$. The results of chemical stimulation of plant defense responses before and after inoculation on infection rates were statistically analyzed using Statistical Package for the Social Sciences (SPSS) version 15.0 (SPSS, Chicago, IL). Welch's t-test with unequal variance was used to examine differences between control groups and various treatment groups were examined $(\mathrm{p}<0.05)$ (Welch, 1947).

\section{RESULTS}

Calibration of basidiospore delivery: The teliosori incubated for $8 \mathrm{~h}$ released an average of 113.8 spores, of which, $18.3 \%$ germinated (Table 2). However, incubating the teliosori for $8 \mathrm{~h}$ with an additional $6 \mathrm{~h}$ lag period led to the release of an average of 1018.9 spores, of which, $44.3 \%$ germinated. Basidiospore release improved with increased incubation times until peak levels were observed by $24 \mathrm{~h}$ yielding an average of 1092 spores without the lag period and 1530.8 with the $6 \mathrm{~h}$ lag period. At all incubation times, basidiospore germination was higher when incubation began after the $6 \mathrm{~h}$ lag time.

PR gene homologs in dyer's woad: The PR-1 gene from dyer's woad had an identity of $91 \%$ with $A$. thaliana and $90 \%$ with B. napus at the nucleotide level. The $\beta$-1, 3-glucanase gene had an identity of $81 \%$ with $A$. thaliana and $95 \%$ with B. napus at the nucleotide level. The ChiA gene from woad had an identity of $94 \%$ with B. napus and $91 \%$ with A. thaliana at the nucleotide level.

Induction kinetics of PR-1, B-1, 3-glucanase and ChiA in dyer's woad: The expression of PR-1 increased to $3.81 \pm 1.32$-fold within $8 \mathrm{~h}$ of rust infection (Fig. 1), but dropped down to the lowest level at $0.29 \pm$ 0.04 -fold within $16 \mathrm{~h}$ of infection. However, by $24 \mathrm{~h}$ PR-1 expression levels started increasing and reached peak levels of $81.69 \pm 33.5$-fold by $36 \mathrm{~h}$. The PR-1 expression levels began to decrease and fell to $1.08 \pm$ 0.76 -fold when sampling stopped at $72 \mathrm{~h}$. When plants were treated with SA, there was a $184.42 \pm 4.53$-fold increase in PR-1 expression in the first $8 \mathrm{~h}$ (Fig. 1). After reaching this peak level within $8 \mathrm{~h}$ of SA application, the levels of expression fell to $0.23 \pm 0.07$ fold at the end $72 \mathrm{~h}$.

Expression of $\beta-1,3$-glucanase increased by 14.22 \pm 0.10 -fold by $8 \mathrm{~h}$ of infection (Fig. 2). After this initial peak, these levels started to decline by $12 \mathrm{~h}$ to $1.51 \pm$ 0.47 -fold. However, the levels of $\beta-1,3$-glucanase started increasing and reached peak levels by the end of $24 \mathrm{~h}$ to $66.77 \pm 8.98$-fold. After attaining peak levels, it declined and reached a level of $3.31 \pm 1.19$-fold by the end of $72 \mathrm{~h}$. On the other hand, application of SA led to peak $\beta-1,3$-glucanase expression levels at $57.8 \pm 10.67$ fold in the first $8 \mathrm{~h}$ (Fig. 2). After reaching these peak levels, the level of expression declined to $6.78 \pm 5.58$ fold by the end of $72 \mathrm{~h}$. 
Am. J. Agri. \& Biol. Sci., 6 (3): 307-316, 2011

Table 2: Dynamics of Puccinia thlaspeos basidiospore germination without and with an incubation period of $6 \mathrm{~h}$

\begin{tabular}{|c|c|c|c|c|c|c|c|c|}
\hline \multirow[b]{2}{*}{ Basidiospores } & \multicolumn{2}{|l|}{$8 \mathrm{~h}$} & \multicolumn{2}{|l|}{$12 \mathrm{~h}$} & \multicolumn{2}{|l|}{$24 \mathrm{~h}$} & \multicolumn{2}{|l|}{$48 \mathrm{~h}$} \\
\hline & $0 \mathrm{~h}$ & $6 \mathrm{~h}$ & $0 \mathrm{~h}$ & $6 \mathrm{~h}$ & $0 \mathrm{~h}$ & $6 \mathrm{~h}$ & $0 \mathrm{~h}$ & $6 \mathrm{~h}$ \\
\hline Total number & 113.8 & 1018.9 & 445.7 & 1424.3 & 1092.1 & 1530.8 & 1036.3 & 1697.5 \\
\hline Number germinated & 20.8 & 451.9 & 232.6 & 1105.7 & 837.2 & 1306.1 & 977.5 & 1662.7 \\
\hline Germination percentage & 18.3 & 44.3 & 52.2 & 77.6 & 76.6 & 85.3 & 94.3 & 97.9 \\
\hline
\end{tabular}

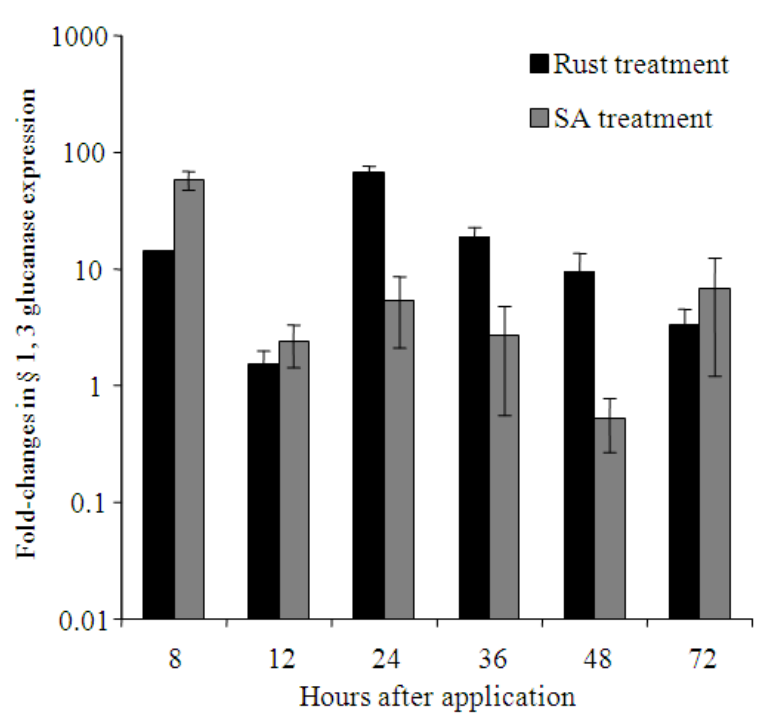

Fig. 2: Relative gene expression of $\beta$-1,3-glucanase seen as a result of treating dyer's woad either with the rust pathogen or $1 \mathrm{mM}$ salicylic acid. Transcript levels were determined using qPCR. Values were normalized with the Actin gene. Each data point was generated from 12 amplifications (3 biological replicates $\mathrm{x} 4$ technical replicates) and is reported as mean $( \pm$ S.E.)

The expression of ChiA increased to $2.62 \pm 0.3-$ fold in the first $8 \mathrm{~h}$ after infection with the rust pathogen (Fig. 3). However, expression started to decline and dropped to a level of $0.96 \pm 0.37$-fold in the next $4 \mathrm{~h}$. On the other hand, the levels of ChiA expression started increasing again and reached peak levels to $7.09 \pm 1.9$-fold by $36 \mathrm{~h}$ of inoculation. After reaching peak level of expression within $36 \mathrm{~h}$, the levels began to decline and dropped to $0.55 \pm 0.3$-fold by $72 \mathrm{~h}$ of exposure.

Exposing dyer's woad to SA led to a $5.89 \pm 0.61$ fold increase in the ChiA expression levels, compared to the calibrator (Fig. 3). After attaining this peak level within $8 \mathrm{~h}$ of exposure, expression fell to $0.71 \pm 0.16$ fold by $72 \mathrm{~h}$ of SA application.

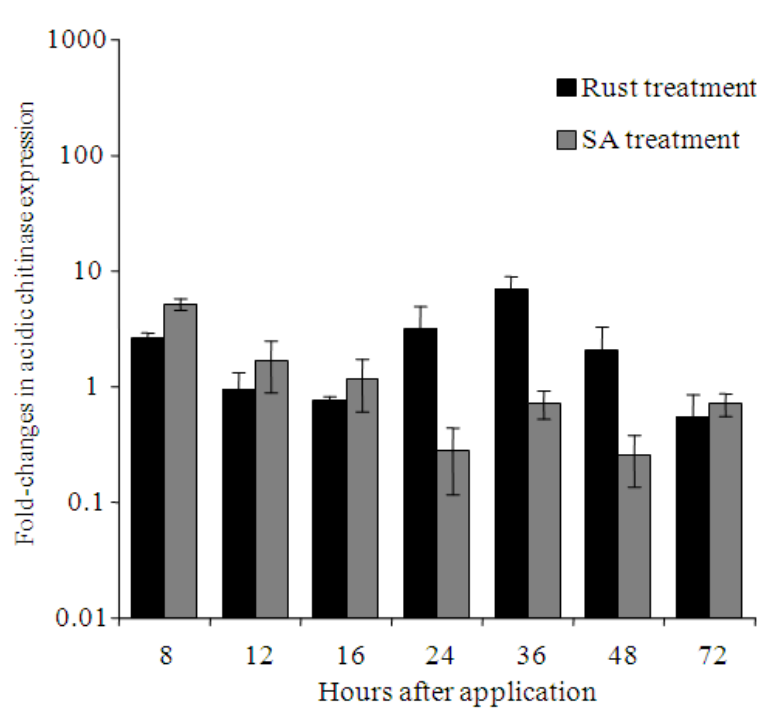

Fig. 3: Relative gene expression of ChiA seen as a result of treating dyer's woad either with the rust pathogen or $1 \mathrm{mM}$ salicylic acid. Transcript levels were determined using qPCR. Values were normalized with the Actin gene. Each data point was generated from 12 amplifications (3 biological replicates $\mathrm{x} 4$ technical replicates) and is reported as mean $( \pm$ S.E. $)$

Effects of SA on rust infection: When SA was first applied $12 \mathrm{~h}$ prior to rust inoculation (pre-penetration phase) the level of PR-1 expression reached a peak level $4 \mathrm{~h}$ prior to the actual event of rust inoculation (Fig. 4) and infection rates were not significantly affected. When the peak defense gene expression was attained prior to inoculation, the infection rate was $90 \%$ with no statistically significant difference between the treatment and the control groups using Welch's t-test (p>0.05) (Fig. 4).

To induce defense responses at the time of basidiospore germination and penetration into dyer's woad, SA was applied at either $8 \mathrm{~h}$ before inoculation or at the time of inoculation. When SA was applied $8 \mathrm{~h}$ prior to rust inoculation, peak levels of PR-1 coincided with the time of rust inoculation and penetration into the plant and the infection rate decreased to $70 \%$ relative to untreated plants. 


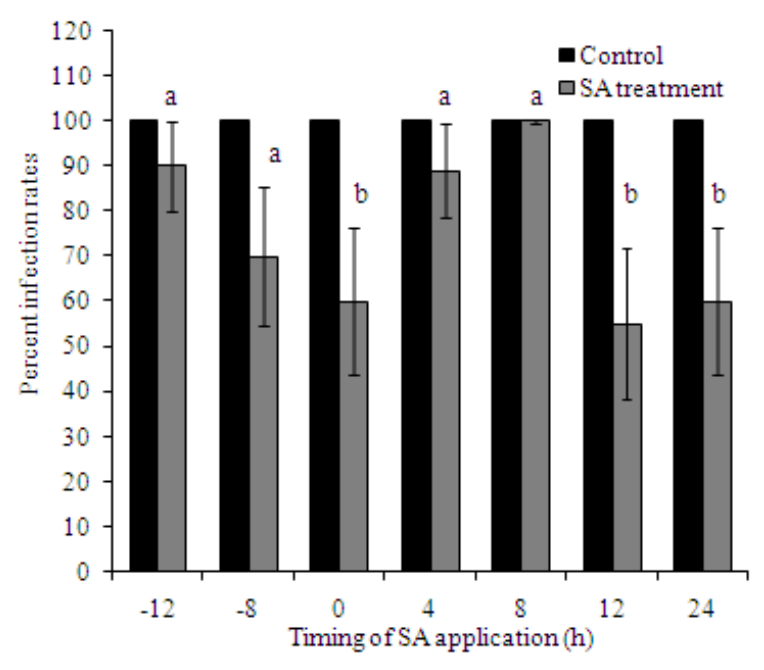

Fig. 4: Rust infection of dyer's woad in response to SA application during key colonization events. A 1 $\mathrm{mM}$ SA solution was applied to the plants before, during and after inoculating dyer's woad with the rust pathogen. Control treatments were sprayed with water in lieu of SA. Infection was detected by PCR using rust-specific primers three weeks after rust inoculation. Means with the same letter (a, a) are not statistically different

Statistically significant differences were found between the treatment and the control group using Welch's t-test $(p<0.05)$. When plants were simultaneously treated with SA and rust inoculum, the peak defense response, coinciding with the prehaustorial phase of infection (Kropp et al., 1999), occurred within $8 \mathrm{~h}$ after inoculation. Infection rates were at $60 \%$ of untreated controls and the difference between the treatment and the control group was statistically significant. Application of SA $4 \mathrm{~h}$ after rust inoculation, at a time coinciding with intercellular hyphal growth (Kropp et al., 1999), led to peak PR-1 expression within $12 \mathrm{~h}$ of inoculation. Activation of the defense response at this time point led to infection rates of $89 \%$ and no statistically significant differences were found between the control and the treatment group in infection levels. Induction of defense responses by application of SA at $8 \mathrm{~h}$ after rust inoculation led to peak levels in defense-related gene expression within $16 \mathrm{~h}$ of inoculation. Infection rates in these plants were found to be at the same level as those of the control group.

SA was also applied to dyer's woad after rust inoculation at times when the rust pathogen had already produced the haustoria and colonized plant tissue (Kropp et al., 1999). When SA was applied to dyer's woad $12 \mathrm{~h}$ after rust inoculation, PR-1 expression occurred within $20 \mathrm{~h}$ of inoculation. Infection rates were $55 \%$ of untreated plants and significantly lower than the control group. Finally, application of SA $24 \mathrm{~h}$ after rust inoculation induced peak defense responses within $32 \mathrm{~h}$ of inoculation. Infection rates at this time point were $60 \%$ of the controls and the difference was statistically significant.

\section{DISCUSSION}

Rusts are obligate parasites and are challenging to work with because of their dependence on living hosts for nutrition and development. Studies focused on the uredial stage of the macrocyclic rusts have been extensive since this is one of the most economically destructive and easily studied stages of the rust cycle. On the other hand, studies on the teliospores produced during the sexual stage of the rusts are limited (Staples, 2000). Teliospores are known to undergo a period of dormancy; consequently, the difficulty in achieving uniform germination has been a key deterrent in dissecting rust-host interactions. Studies have suggested that washing the teliospores and stimulating teliospore germination in the dark, are some of the most effective treatments in overcoming dormancy (Gold and Mendgen, 1983). In the current study, teliospores of $P$. thlaspeos produced the most basidiospores after being washed and incubated in the dark for $24 \mathrm{~h}$ after allowing for a $6 \mathrm{~h}$ lag time (Table 2). Both average basidiospore production per sorus and spore germination increased with increased incubation time to $24 \mathrm{~h}$. Thus, uniform numbers of basidiospores can be delivered per unit leaf surface area for each experiment by adjusting both the incubation time and the number of sori used.

Nonhost resistance to rust fungi is generally expressed early in the interaction before haustorium formation so that biotrophic pathogens are often not able to enter nonhost tissue (Heath, 1981; Mellersh et al., 2002). Although reports in the literature differ somewhat regarding the response of SA-mediated genes to fungal infections of plants (Gus-Mayer et al., 1998; Mellersh and Heath, 2003), our work found that all three of the pathogen-induced, SA-responsive genes we studied were upregulated during germination and penetration into plant tissue. During the initial stages of infection, both PR-1 and ChiA showed modest increases in expression levels (Fig. 1 and 3) while the up-regulation of $\beta-1,3-$ glucanase was more pronounced (Fig. 2).

Despite the up-regulation of genes coding for antimicrobial proteins, rust infection of dyer's woad was successful. Rust fungi have been observed to negate non-specific defense responses in both resistant 
and susceptible cells early in the infection process in order to establish biotrophy in a potential host plant (Heath, 1998). It is not known yet unambiguously whether the dyer's woad pathogen uses this mechanism to infect its host. However, our results show that exogenous application of SA to healthy plants led to a sharp increase in expression of PR-1, $\beta-1,3$-glucanase and ChiA during the first $8 \mathrm{~h}$ after treatment (Fig. 1-3) and that it appears to reprogram the host to exhibit increased resistance towards the pathogen, particularly during basidiospore germination and host penetration (Fig. 4). However, the timing of SA application appears to be critical, since applying SA $12 \mathrm{~h}$ before inoculation did not affect infection rates but applying it at the time of basidiospore germination and penetration into the plant, induced plant resistance to the rust pathogen (Fig. 4). These findings are similar to earlier studies by Rauscher et al. (1999) who concluded that Uromyces fabae was inhibited immediately after penetration of the host due to the antifungal activity of the PR-1 protein, brought about by exogenous application of SA.

In our work, expression levels of PR-1, $\beta-1,3-$ glucanase and ChiA were lower for inoculated plants at $12 \mathrm{~h}$ and $16 \mathrm{~h}$ after inoculation, a time corresponding to haustorium formation (Kropp et al., 1999), than they were for the mock-inoculated controls (Fig. 1-3). Thus, it is apparent that there is a suppression of PR genes that coincides with haustorium formation in dyer's woad. This finding is consistent with other biotrophic interactions where suppression of defense responses has been reported during haustoria formation. For example, formation of intracellular haustoria by an Uromyces sp., involves the suppression of defense responses (Heath, 1997; Heath and Skalamera, 1997). The powdery mildew pathogen Blumeria graminis f. sp. hordei was reported to suppress basal plant defense responses in barley at the time haustoria formation (Caldo et al., 2004; 2006). In another study of powdery mildew infection of barley, failed infections corresponded with transcriptional upregulation of PR genes such as the peroxidase-encoding gene, Prx8 and the oxalate oxidase-encoding gene, GRP94 (Gregersen et al., 1997). Reduced levels of SA in Arabidopsis mutants sid2 and NahG also promoted haustorium formation in these plants by Uromyces sp. (Mellersh and Heath, 2003).

Although applying SA during the haustorial phase would theoretically inhibit haustorium formation by triggering defense gene expression, exogenous application of SA in our work during haustorium formation did not over-ride the pathogen-induced suppression of defense responses, since infection rates were unchanged (Fig. 4). Even though nonhost resistance to rust fungi is generally expressed prior to the formation of haustoria (Heath, 1981), the host resistance triggered by recognition of the pathogen avirulence gene product that leads to a hypersensitive response occurs after haustoria form (Heath, 1980). Thus, formation of haustoria without stimulating host defense responses is of vital importance to the establishment of biotrophic relationships (Mendgen and Hahn, 2002; Mendgen et al., 2000; Panstruga, 2003; Perfect and Green, 2001; Schulze-Lefert and Panstruga, 2003). After haustorium formation, there was another increase in expression of PR genes in infected dyer's woad (Fig. 1-3). However, after PR expression reached peak levels, there was a steady decline in expression as measured at 48 and $72 \mathrm{~h}$ after inoculation. Similar declines in nonspecific defense responses in compatible barley-powdery mildew interactions have been noted (Caldo et al., 2004). Also, wheat infected with powdery mildew showed an initial accumulation of PR genes WIR1 and WIR2 that later declined as the pathogen colonized the host (Waspi et al., 2001).

When exogenous application of SA was done at 12 $\mathrm{h}$ and $24 \mathrm{~h}$ after inoculation, peak levels of PR gene expression occurred $20 \mathrm{~h}$ and $32 \mathrm{~h}$ after rust infections and significantly lowered infection rates (Fig. 4). The antifungal activity of each of the PR proteins used in the current study has been well documented (Mauch et al., 1988; Rauscher et al., 1999; Sela-Buurlage et al., 1993) but it is not known whether pathogen inhibition is dependent on the amount of PR expression. However, exogenous SA application led to a 184-fold expression of PR-1, while the pathogen only induced a 81 -fold expression of the same. Thus, it appears that, in our system, pathogen-induced PR expression is insufficient to inhibit fungal growth during the compatible interaction between dyer's woad and the rust pathogen.

During rust infection of dyer's woad, the suppression of defense responses was seen during two phases, one at the haustorial phase and the other, after haustorium formation. Although the first pathogenmediated suppression was short term and likely facilitated haustorium formation, the second suppression event was more significant in establishing a biotrophic relationship because this suppression is relatively long-term, occurring after invasion of host tissue. It is possible that the induction events seen in dyer's woad before and after haustoria formation are brought about by two different mechanisms. For instance, one study examining nonhost resistance to different rust fungi using Arabidopsis signaling mutants such as sid2, NahG and npr1, found that although SAdependent responses were involved in suppressing haustorium formation, it was NPR1-independent (Mellersh and Heath, 2003). However, the R-gene 
mediated defense response seen after haustorium formation is typically NPR1-dependent (Glazebrook, 2005; Rairdan and Delaney, 2002).

Previous studies have implicated the haustoria not only in nutrient acquisition, but also in the suppression of defense responses during compatible interactions (Panstruga, 2003). The mechanism by which $P$. thlaspeos suppresses defense responses either at haustorial phase or the posthaustorial phase is unknown but it could be brought about either by pathogenderived or plant-derived suppressor molecules. As an example, host cell wall-derived oligomers of galacturonic acid suppress the activity of phenylalanine ammonia lyase and peroxidases in infections by the wheat stem rust $P$. graminis f. sp. tritici (Moerschbacher et al., 1999). Another factor that could potentially play a role in woad infection by woad rust is the dominant inhibitor of avirulence (I) gene that modifies the outcome of a specific R-Avr gene interaction from resistance to susceptibility (Jones, 1988a; 1988b; Lawrence et al., 1981). It is not yet known whether the I gene plays a role in the susceptibility seen during the dyer's woad-rust interaction.

\section{CONCLUSION}

During the initial stages of rust infection, modest increases in expression levels of genes coding for antimicrobial proteins were observed. However suppression of these defense responses were observed during haustorium formation. After haustorium formation, there was another increase in expression of PR genes in infected dyer's woad, which in turn, was followed by another long-term pathogen-induced suppression of the defense response that appears to allow successful infections in dyer's woad. It appears that haustoria produced by $P$. thlaspeos, plays a vital role not only in acquiring nutrients but also in the longterm colonization of the host. Further investigation into the tools employed by the rust pathogen in suppression of defense responses is important to more fully understand compatibility in host-pathogen interactions and the establishment of biotrophy. The interaction between dyer's woad and $P$. thlaspeos provides a good platform to make such determinations.

\section{ACKNOWLEDGEMENT}

Dr. Tim Gilbertson is thanked for generously allowing access to the equipment needed for our realtime PCR studies. Dr. Dane Hansen is thanked for providing valuable advice about real-time PCR protocols during the course of this study. The Utah Agricultural Experiment Station is thanked for financial support. This is Utah Agricultural Experiment Station paper.

\section{REFERENCES}

Caldo, R.A., D. Nettleton and R.P. Wise, 2004. Interaction-dependent gene expression in Mlaspecified response to barley powdery mildew. Plant Cell, 16: 2514-2528. DOI: 10.1105/tpc.104.023382

Caldo, R.A., D. Nettleton, J. Peng and R.P. Wise, 2006. Stage-specific suppression of basal defense discriminates barley plants containing fast- and delayed-acting Mla powdery mildew resistance alleles. Mol. Plant Microbe Interact., 19: 939-947. DOI: 10.1094/MPMI-19-0939

Cooper, R.M., 1984. Cell wall Degrading Enzymes. In: Plant Disease: Infection Damage and Loss, Wood R.K.S and G.J. Jellis (Eds.). Blackwell Publishing, Oxford, UK, pp: 13-27. ISBN: 0632011262

Dodds, P.N., G.J. Lawrence, A.M. Catanzariti, M.A. Ayliffe and J.G. Ellis, 2004. The Melampsora lini AvrL567 avirulence genes are expressed in haustoria and their products are recognized inside plant cells. Plant Cell, 16: 755-768. DOI: 10.1105/tpc.020040

Dodds, P.N., G.J. Lawrence, A.M. Catanzariti, T. The and C.I. Wang, et al., 2006. Direct protein interaction underlies gene-for-gene specificity and coevolution of the flax resistance genes and flax rust avirulence genes. Proc. Natl. Acad. Sci., 103: 8888-8893. DOI: 10.1073/pnas.0602577103

Flor, H.H., 1956. The complementary genic systems in flax and flax rust. Adv. Genet., 8: 29-54. DOI: 10.1016/S0065-2660(08)60498-8

Flor, H.H., 1971. Current status of the gene-for-gene concept. Annu. Rev. Phytopathol., 9: 275-296. DOI: 10.1146/annurev.py.09.090171.001423

Glazebrook, J., 2005. Contrasting mechanisms of defense against biotrophic and necrotrophic pathogens. Annu. Rev. Phytopathol., 43: 205-227. DOI: 10.1146/annurev.phyto.43.040204.135923

Gold, R.E. and K. Mendgen, 1983. Activation of teliospore germination in Uromyces appendiculatus var. appendiculatus II. Light and host volatiles. J. Phytopathol., 108: 281-293. DOI: 10.1111/j.1439-0434.1983.tb00589.x

Gregersen, P.L., H. Thordal-Christensen, H. Forster and D.B. Collinge, 1997. Differential gene transcript accumulation in barley leaf epidermis and mesophyll in response to attack by Blumeria graminis f. sp. hordei (syn. Erysiphe graminis f. sp. hordei). Physiol. Mol. Plant Pathol., 51: 85-97. DOI: 10.1006/pmpp.1997.0108 
Gus-Mayer, S., B. Naton, K. Hahlbrock and E. Schmelzer, 1998. Local mechanical stimulation induces components of the pathogen defense response in parsley. Proc. Natl. Acad. Sci., 95: 8398-8403.

http://www.pnas.org/content/95/14/8398.full

Heath, M.C. and D. Skalamera, 1997. Cellular interaction between plants and biotrophic fungal parasites. Adv. Bot. Res., 24: 195-225. DOI: 10.1016/S0065-2296(08)60074-9

Heath, M.C., 1980. Effects of infection by compatible species or injection of tissue extracts on the susceptibility of nonhost plants to rust fungi. Phytopathology, 70: 356-360. DOI: 10.1094/Phyto-70-356

Heath, M.C., 1981. Resistance of plants to rust infection. Phytopathology, 71: 971-974. DOI: 10.1094/Phyto-71-971

Heath, M.C., 1997. Signaling between pathogenic rust fungi and resistant or susceptible host plants. Ann. Bot., 80: 713-720. DOI: 10.1006/anbo.1997.0507

Heath, M.C., 1998. Involvement of reactive oxygen species in the response of resistant (hypersensitive) or susceptible cowpeas to the cowpea rust fungus. New Phytol., 138: 251-263. DOI: 10.1046/j.14698137.1998.00897.x

Heath, M.C., 2003. Nonhost Resistance in Plants to Microbial Pathogens. In: Infectious Disease: Innate Immunity, Ezekowitz R.A.B. and J.A. Hoffmann (Eds.). Humana Press, NJ, USA., pp: 47-57. ISBN: 1588290468

Jones, D.A., 1988a. Genes for resistance to flax rust in the flax cultivars towner and victory $\mathrm{A}$ and the genetics of pathogenicity in flax rust to the $L 8$ gene for resistance. Phytopathology, 78:338-341. DOI: 10.1094/Phyto-78-338

Jones, D.A., 1988b. Genetic properties on inhibitor genes in flax rust that alter avirulence to virulence on flax. Phytopathology, 78: 342-344. DOI: 10.1094/Phyto-78-342

Kropp, B.R. and H. Darrow, 2006. The effect of surfactants and some herbicides on teliospore viability in Puccinia thlaspeos (Schub.). Crop Prot., 25: 369-374. DOI: 10.1016/j.cropro.2005.06.004

Kropp, B.R., D. Hansen and S.V. Thomson, 2002. Establishment and dispersal of Puccinia thlaspeos in field populations of dyer's woad. Plant Dis., 86: 241-246. DOI: 10.1094/PDIS.2002.86.3.241

Kropp, B.R., D. Hansen, K.M. Flint and S.V.Thomson, 1996. Artificial inoculation and colonization of dyer's woad (Isatis tinctoria) by the systemic rust fungus Puccinia thlaspeos. Phytopathology, 86: 891-896. DOI: 10.1094/Phyto-86-891
Kropp, B.R., G.R. Hooper, D. Hansen, M. Binns and S.V. Thomson, 1999. Initial events in the colonization of dyer's woad by Puccinia thlaspeos. Can. J. Bot., 77: 843-849. DOI: 10.1139/cjb-77-6-843

Lawrence, G.J., G.M.E. Mayo and K.W. Shepherd, 1981. Interactions between genes controlling pathogenicity in the flax rust fungus. Phytopathology, 71: 12-19. DOI: 10.1094/Phyto71-12

Mauch, F., B.M. Mani and T. Boller, 1988. Antifungal hydrolases in pea tissue: II. Inhibition of fungal growth by combinations of chitinase and beta-1,3glucanase. Plant. Physiol., 88: 936-942. DOI: 10.1104/pp.88.3.936

Mellersh D.G., I.V. Foulds, V.J. Higgins and M.C. Heath, 2002. $\mathrm{H}_{2} \mathrm{O}_{2}$ plays different roles in determining penetration failure in three diverse plant-fungal interactions. Plant J., 29: 257-268. DOI: 10.1046/j.0960-7412.2001.01215.x

Mellersh, D.G. and M.C. Heath, 2003. An investigation into the involvement of defense signaling pathways in components of the nonhost resistance of Arabidopsis thaliana to rust fungi also reveals a model system for studying rust fungal compatibility. Mol. Plant Microbe Interact., 16: 398-404. DOI: 10.1094/MPMI.2003.16.5.398

Mendgen, K. and M. Hahn, 2002. Plant infection and the establishment of fungal biotrophy. Trends Plant Sci., 7: 352-356. DOI: 10.1016/S13601385(02)02297-5

Mendgen, K., C. Struck, R.T. Voegele and M. Hahn, 2000. Biotrophy and rust haustoria. Physiol. Mol. Plant Pathol., 56: 141-145. DOI: 10.1006/pmpp.2000.0264

Moerschbacher, B.M., M. Mierau and B. Graessner, U. Noll and A.J. Mort, 1999. Small oligomers of galacturonic acid are endogenous suppressors of disease resistance reactions in wheat leaves. J. Exp. Bot., 50: 605-612. DOI: 10.1093/jxb/50.334.605

Panstruga, R., 2003. Establishing compatibility between plants and obligate biotrophic pathogens. Curr. Opin. Plant Biol., 6: 320-326. DOI: 10.1016/S1369-5266(03)00043-8

Perfect, S.E. and J.R. Green, 2001. Infection structures of biotrophic and hemibiotrophic fungal plant pathogens. Mol. Plant Pathol., 2: 101-108. DOI: 10.1046/j.1364-3703.2001.00055.x

Rairdan, G.J. and T.P. Delaney, 2002. Role of salicylic acid and NIM1/NPR1 in race-specific resistance in arabidopsis. Genetics, 161: 803-811. http://www.genetics.org/content/161/2/803.full.pdf + html 
Rauscher, M., A.L. Adam, S. Wirtz, R. Guggenheim, K. Mendgen and H.B. Deising, 1999. PR-1 protein inhibits the differentiation of rust infection hyphae in leaves of acquired resistant broad bean. Plant J., 19: 625-633. DOI: $10.1046 / \mathrm{j} .1365-$ 313x.1999.00545.x

Schulze-Lefert, P. and R. Panstruga, 2003. Establishment of biotrophy by parasitic fungi and reprogramming of host cells for disease resistance. Annu. Rev. Phytopathol., 41: 641-667. DOI: 10.1146/annurev.phyto.41.061002.083300

Sela-Buurlage, M.B., A.S. Ponstein, S.A.B. Vloemans, L.S. Melchers and P.J.M. Van Den Elzen et al., 1993. Only specific tobacco (Nicotiana tabacum) chitinases and [beta]-1,3-glucanases exhibit antifungal activity. Plant Physiol., 101: 857-863. DOI: $10.1104 /$ pp.101.3.857

Staples, R.C., 2000. Research on the rust fungi during the twentieth century. Annu. Rev. Phytopathol., 38: 49-69. DOI: 10.1146/annurev.phyto.38.1.49

Thomas, E. and B.R. Kropp, 2009. Analysis of isolation and expression analysis of ItCYP79B2 during rust infection of dyer's woad (Isatis tinctoria) by Puccinia thlaspeos. Can. J. of Plant Pathol., 31: 103-107. DOI: 10.1080/07060660909507578

Thomas, E. and B.R. Kropp, 2011. Some effects of abiotic stress on infection of dyer's woad (Isatis tinctoria L.) by Puccinia thlaspeos $C$. Schub.:Implications for biological control. Amer. J. Agri. Biol. Sci., 6: 45-51. DOI: 10.3844/ajabssp.2011.45.51
Thomma, B.P., I.A. Penninckx, W.F. Broekaert and B.P. Cammue, 2001. The complexity of disease signaling in Arabidopsis. Curr. Opin. Immunol., 13: 63-68. DOI: 10.1016/S0952-7915(00)00183-7

Thordal-Christensen, H., 2003. Fresh insights into processes of nonhost resistance. Curr. Opin. Plant Biol., 6: 351-357. DOI: 10.1016/S13695266(03)00063-3

Van Loon, L.C., M. Rep and C.M. Pieterse, 2006. Significance of inducible defense-related proteins in infected plants. Annu. Rev. Phytopathol., 44: 135-162. DOI: 10.1146/ annurev.phyto.44.070505.143425

Waspi, U., P. Schweizer and R. Dudler, 2001. Syringolin reprograms wheat to undergo hypersensitive cell death in a compatible interaction with powdery mildew. Plant Cell, 13: 153-161. DOI: 10.1105/tpc.13.1.153

Welch, B.L., 1947. The generalization of "student's" problem when several different population variances are involved. Biometrika, 34: 28-35. DOI: 10.1093/biomet/34.1-2.28 